\title{
Technological Innovation in the Electro-Medical Equipment Sector: Analysis in Latin America
}

\author{
César Antonio Pereira', Asa Fujino², Marco Antonio Silveira ${ }^{3}$
}

\begin{abstract}
It is an exploratory study of technological innovation in the electro-medical equipment sector, encompassing an analysis of trends in Latin America. The methodological bases for the study are the procedures and indicators used in bibliometric studies and it uses as its body of analysis the invention patents available in the European Patent Office. The research study made it possible to perform qualitative analyses aimed at understanding the technological innovation behavior of institutions operating in the area. It also allowed us to show the relative position of each company, sector or country in relation to the potential competition. It is hoped that these results will be able to provide support for public policies which underpin innovation in this sector.
\end{abstract}

Keywords: technological innovation management; electro-medical equipment; patents; patent bibliometry; technology trends in latin america.

Post-Graduate Program in Information Science, School of Communication and Arts, University of São Paulo (USP). Av. Prof. Lúcio Martins Rodrigues, 443, CEP 05508-020, São Paulo, SP, Brazil. Phone: 55 II 309|-40I9.E-mail: I cesarpereira@usp.br, ${ }^{2} a s f u j i n o @ u s p . b r$

${ }^{3}$ G.A.I.A. / Support Group for Innovation and Learning in Organizations, CTI-MCTI/Center for Information Technology Renato Archer, Rod. D. Pedro I, km I43, CEP: I3069-90 I, Campinas, SP, Brazil. Phone: 55 I9 3746-6083. E-mail: marco.silveira@cti.gov.br 


\section{Introduction}

The dramatic and increasing reduction in the time required for the development and incorporation of scientific activities into technological and production processes has made the innovation cycle increasingly shorter and more of a challenge, placing demands on governments, businesses and universities for quicker and more integrated forms of participation.

New innovation models are dealt with by Moreira and Velho (2008), showing that knowledge is produced concurrently with its application, often eliminating the gap between the production and application scenarios. In this new model, intellectual authorship merges with ownership rights from which emerges the symbol of the patent document.

The product of an accommodation between the creation of knowledge and the potential for strategic application in the innovation of products or processes, the patent is of fundamental importance to the system of innovation: on the one hand it is the guarantee which safeguards against the appropriation of new technologies by third parties prior to the expiry of the period granted to the holder of the exploitation rights, but on the other hand, it also demonstrates the stage of the growth in technological research in companies, industrial sectors, countries and regions. Using information content included in the patent documents, indicators are created which, amongst others, help with the resolution of specific technological problems, in determining the characteristics of cooperation in innovation, in the appreciation of the technological balance sheet, the analysis of the historical and evolving development of technology and, crucially, the improvement of companies' competitiveness. Moreover, these analyses permit us not only to find out but also to describe and rate the content and the flow of information mobilized in the construction of innovation knowledge, to assist with understanding and evaluating the capacity for innovation, paint a picture of the progress being made with innovative activities, help with the establishment and/or updating of policies and technology management, whatever the sector, country or region (Narin; Olivastro, 1992; Narin, 1994, 1995; Callon, Courtial, and Penan, 1995; Schmouch, 1997; Meyer, 2000; Spinak, 2003).

Researchers in various fields of knowledge, particularly Information Science (Fujino, 2006; Hyodo, 2010; Maricato, 2010), have dedicated themselves to research aimed at a better understanding of the relationship between scientific and technological production, so as to provide support for public policies that foster innovation, that will make it possible to shorten the time and processes for getting the results of the research into production. On the other hand, bibliometric studies have been carried out (Maricato, 2010;
Pereira; Bazi, 2009) with the aim of painting a picture of the stages of development in specific sectors or countries, using a variety of indicators including patent production. These studies have shown themselves to be extremely promising in identifying institutional or government policies that sometimes encourage basic research via direct financial support to researchers or academic research groups, or foster cooperation between the stakeholders in the same innovation network or support the production sector by way of policies of duty exemptions or fiscal incentives.

Though heavily quantitative, they do enable qualitative analyses aimed at understanding the technological or innovative behaviors of companies operating in the area of knowledge or within the limits established by the analysis. For the success of these studies, a significant contribution is made by methods that permit cross-analyses to be made between patents, holders of ownership rights, authors/inventors and, above all, contextual analyses that take into account government policies and actions, business associations etc. in parallel with the numerical application data.

Nevertheless, studies on patent capacity or the behavior of many companies are still not sufficient, which makes it difficult to perform sector or global analyses.

With the coming of new information and communication technologies, as well as the advent of the internet and policies of transparency adopted by various government bodies, access to patent databases has enabled advances in this type of study, with a significant possibility of contributing to an improvement in the management of innovation in companies or countries, since if, on the one hand, the current scenario is epitomized by competitiveness between businesses, on the other hand, studies of this kind allow the relative position of each business, sector or country to be demonstrated in relation to its potential competitors. For governments, it is essential for providing the support for public policies, hence the importance and relevance of this type of study within the realm of Administration and particularly for studies into innovation management.

In selecting the electro-medical equipment sector, this study seeks to plug a gap in our understanding of the stage of development of the technological research of companies, sectors, countries and regions in a high-technology sector and steady funding in various different countries. Being technology-intensive and subject to strong international competition, and due to its social nature, being connected to the health services, responsible for the significant investment of small, medium and large-sized companies, it is extremely important to understand the characterization of this sector within Latin America. 
In this regard, the aim of the present study is to identify and analyze the technological production represented by patents in the global electro-medical equipment sector, the biggest producing agents (companies, universities), the relationships between them, the history of production, the positioning of technology and its characterization in Latin America, as compared to other regions.

\section{Methods}

This is a descriptive study with an exploratory outline founded on bibliometric procedures and, as proposed by Gil (2002), it seeks to make it possible to enrich ideas and explain the causal variables of global development in the electro-medical equipment sector, particularly the complex situations in Latin America. The following methodological procedures were adopted:

Collection and Organization of the Data: patent records were retrieved electronically, using the commercial software Matheo Patent, in respect of the global electromedical equipment sector represented, according to the International Patent Classification (IPC), under code A6IN (Electrotherapy; Magnetotherapy; Radiation Therapy; Ultrasound Therapy) in the European Patent Office database (Esp@cenet).

Data analysis: all the data were processed and measured using bibliometric and scientometric techniques for evaluating scientific and technological production, especially patent production, coined as patent bibliometry (Callon, Courtial, and Penan, 1995) or patentometry (Guzman Sanchez, 1999). The data were analyzed using the Dataview software appli- cation for measuring data and execution of the results. The identified data were graphed using the Microsoft Excel and Ucinet / NetDraw programs.

\section{Results and Discussion}

A total of 169,756 records were retrieved from the European Patent Office database (Esp@cenet) of patents, in the electro-medical equipment sector, filed globally between $196 \mathrm{I}$ and 2010 (Appendix I). Based on this survey, it was possible to paint a picture of technological development in the sector and of the policies of innovation management adopted in Latin America. Four indicators were evaluated for this purpose:

- total number of records for Latin America: of the total of 169,756 patent records worldwide, 1,687 records were identified as being filed in Latin America, corresponding to approximately I\% of global production. Of the Latin America total, three countries in particular stand out in terms of the registration of applications (Graph I).

Of the Latin American countries with records of patent applications in the electro-medical equipment sector, Brazil, Mexico and Argentina feature most prominently with $99 \%$ of all applications. Compared with the total worldwide production in this sector, they are among the top 40 countries in patent applications, as follows: Brazil (16th), Mexico (25th) and Argentina (40th), led by the USA (Ist), Japan (2nd) and China (3rd). Other Latin American countries such as Ecuador (6Ist), Cuba and Peru (62nd), Uruguay (63rd), Chile, Costa Rica and Panamá (65th) also have a record of patents filed in this sector, though fairly insignificant.

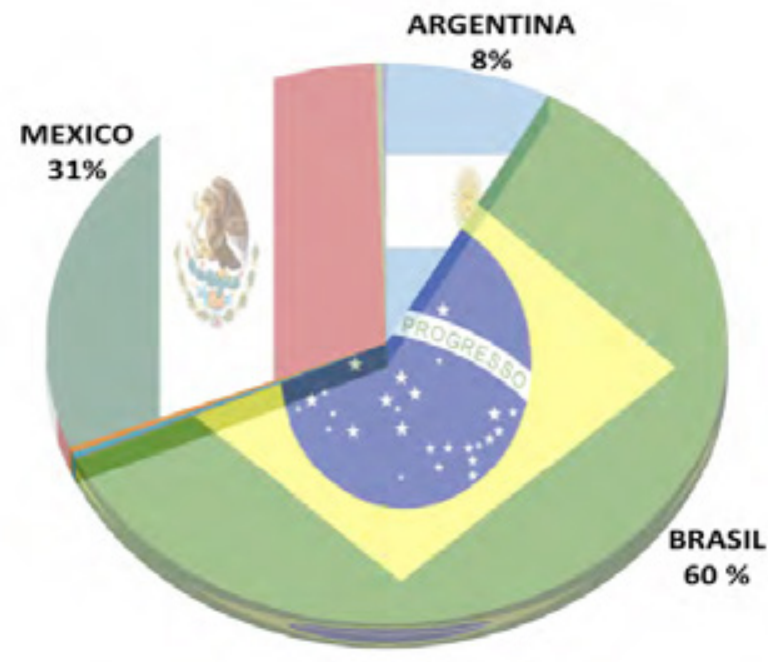

Graph I. Latin American countries with the largest recording of patent applications in the electro-medical equipment sector between 1961 and 2010.

ISSN: 07 I8-2724. (http://www.jotmi.org) 
- historical evolution of production: the production of patents in the electro-medical equipment sector filed in Latin American countries is spread over a period of 37 years (1973-2010).Viewed in terms of years, the production in the sector, with the exception of 1995 and 1996, is marked by a quantitative evolution in patent applications. (Graph 2).

Of the total number of years with patent applications in this sector, two distinct periods can be noted. In the first period, between 1973 and $200 \mathrm{I}$, which represents $50 \%$ of the total production, there was an annual average of 29 patents filed in the countries of Latin America. In the second period, between 2002 and 2010, there is a significant growth in applications in the sector, particularly between 2004 and 2006, years in which production reached a peak and represented $21 \%$ of all the years of patent applications. Therefore, in Latin America, the historical evolution of patent production in the sector is marked by a growing evolution in the total number of applications over a period of 37 years, and particularly during the last decade.

- producing agents: a total of $\mathrm{I}, \mathrm{I} I 3$ producing agents were identified of electro-medical equipment with patent applications in the countries of Latin America, an average of 1.5 patents per agent. Out of this total number of applications in Latin America, approximately $98 \%$ are producing agents represented by companies or individuals, and $2 \%$ universities.

Of the producing universities in Latin America with patent applications in this sector, the applications by North American universities and Brazilian universities dominate with a production of $58 \%$ and $25 \%$ per university, respectively. Distributed numerically by country, there are 17 North
American, 5 Brazilian, 2 Canadian universities and 4 universities distributed through Italy, Australia, Great Britain and France (Table I).

With regard to the companies with the largest number of patent applications in the electro-medical equipment sector in Latin America, 20 companies are listed between 1973 and 2010 . Of these, 16 are North American companies, including Johnson \& Johnson, Alza Corp., Medtronic Inc., Becton Dickinson Co., Drug Delivery Systems Inc., Ivivi Technologies Inc., Minnesota Mining and Manufacturing Co. and Science Medicus Inc., which together represent $18 \%$ of the total number of applications (Graph 3).

Out of the total number of patent applications by companies in this sector, in the countries of Latin America, a heavy predominance of North American companies was noted, with $38 \%$ of patents filed. Brazilian companies and research entities figure in second place in total applications, with approximately $25 \%$ and specifically all the patents are filed in Brazil. Adding together the applications of Latin American companies assigned to Brazil, Mexico, Argentina, Peru, Cuba, Chile and Uruguay, the Latin America region accounted for $31 \%$ of the total applications filed.

Companies assigned to Germany, Japan, Great Britain, France, Italy, Canada, Israel, Switzerland, Spain, Hungary, The Netherlands, Norway, Sweden and Belgium, were represented significantly with $24 \%$ of the total number of companies filing applications in this sector in the countries of Latin America. Finally, Asian companies assigned to countries such as Japan, China, South Korea, Russia and Taiwan, correspond to $4 \%$ of total applications (Graph 4).

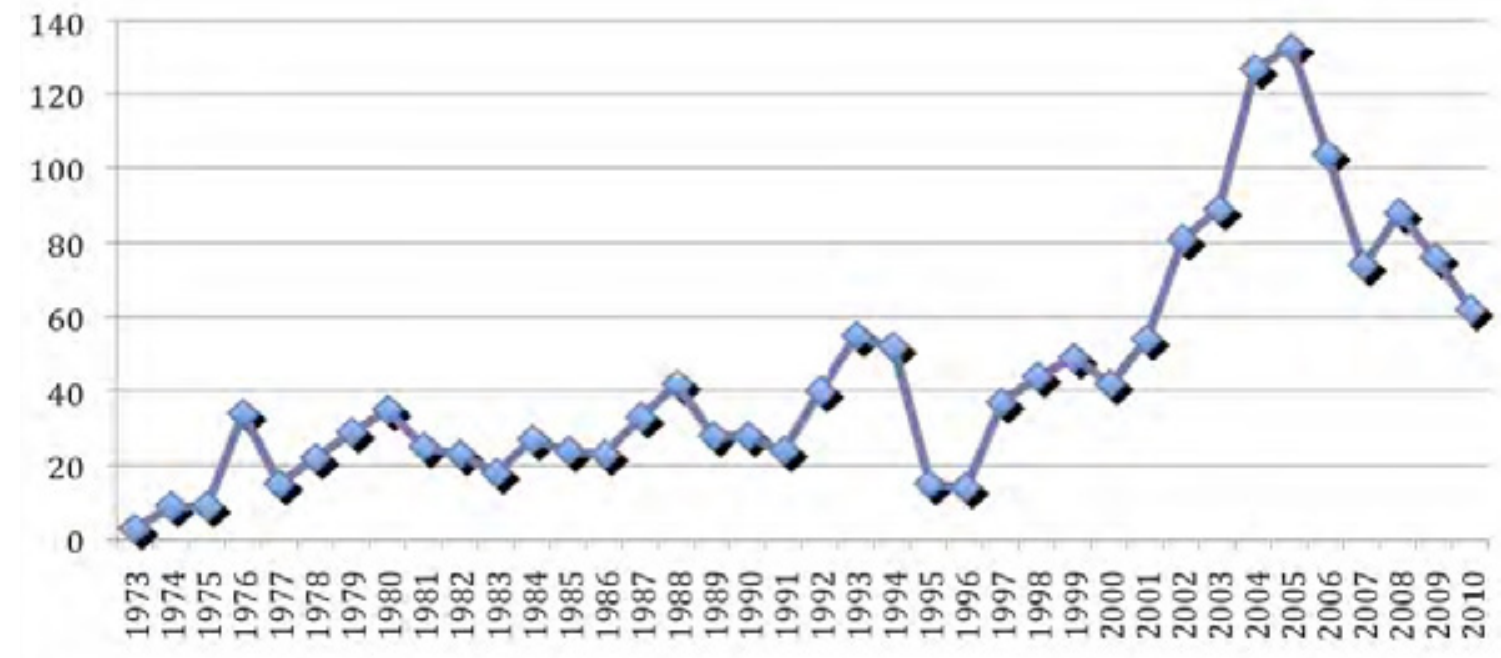

Graph 2. Historical evolution of patent applications in the electro-medical equipment sector in Latin American countries between 1973 and 2010.

ISSN: 07I 8-2724. (http://www.jotmi.org)

Journal of Technology Management \& Innovation (c) Universidad Alberto Hurtado, Facultad de Economía y Negocios. 


\begin{tabular}{|c|c|c|}
\hline University & Country & Records \\
\hline Univ Alberta & Canada & 2 \\
\hline Univ America Catholic & USA & $\mathrm{I}$ \\
\hline Univ Bristol & United Kingdon & $\mathrm{I}$ \\
\hline Univ Brown Res Found & USA & $\mathrm{I}$ \\
\hline Univ California & USA & 4 \\
\hline Univ Columbia & USA & $\mathrm{I}$ \\
\hline Univ Degli Studi Udine & Italy & $\mathrm{I}$ \\
\hline Univ Emory & USA & $\mathrm{I}$ \\
\hline Fed Univ São Paulo & Brazil & $\mathrm{I}$ \\
\hline Fed Univ Paraíba & Brazil & $\mathrm{I}$ \\
\hline Univ Georgetown & USA & $\mathrm{I}$ \\
\hline Univ Houston System & USA & $\mathrm{I}$ \\
\hline Univ Jefferson & USA & $\mathrm{I}$ \\
\hline Univ Loma Linda Med & USA & 2 \\
\hline Univ Luterana Brasil & Brazil & $\mathrm{I}$ \\
\hline Fed Univ Minas Gerais & Brazil & 5 \\
\hline Univ Missouri & USA & $\mathrm{I}$ \\
\hline Univ Montpellier II & France & 1 \\
\hline Univ Montreal & Canada & 1 \\
\hline Univ New York & USA & $\mathrm{I}$ \\
\hline Univ Pennsylvania & USA & 3 \\
\hline Univ São Paulo & Brazil & 3 \\
\hline Univ Southern California & USA & $\mathrm{I}$ \\
\hline Univ Technology Sidney & Australia & $\mathrm{I}$ \\
\hline Univ Texas & USA & 2 \\
\hline Univ Utah Res Found & USA & 2 \\
\hline Univ West Virginia & USA & $\mathrm{I}$ \\
\hline Univ Wyoming Res Corp & USA & 1 \\
\hline TOTAL & & 43 \\
\hline
\end{tabular}

Table I. Producing universities with patent applications in the electro-medical equipment sector in Latin America between 1973 and 2010.

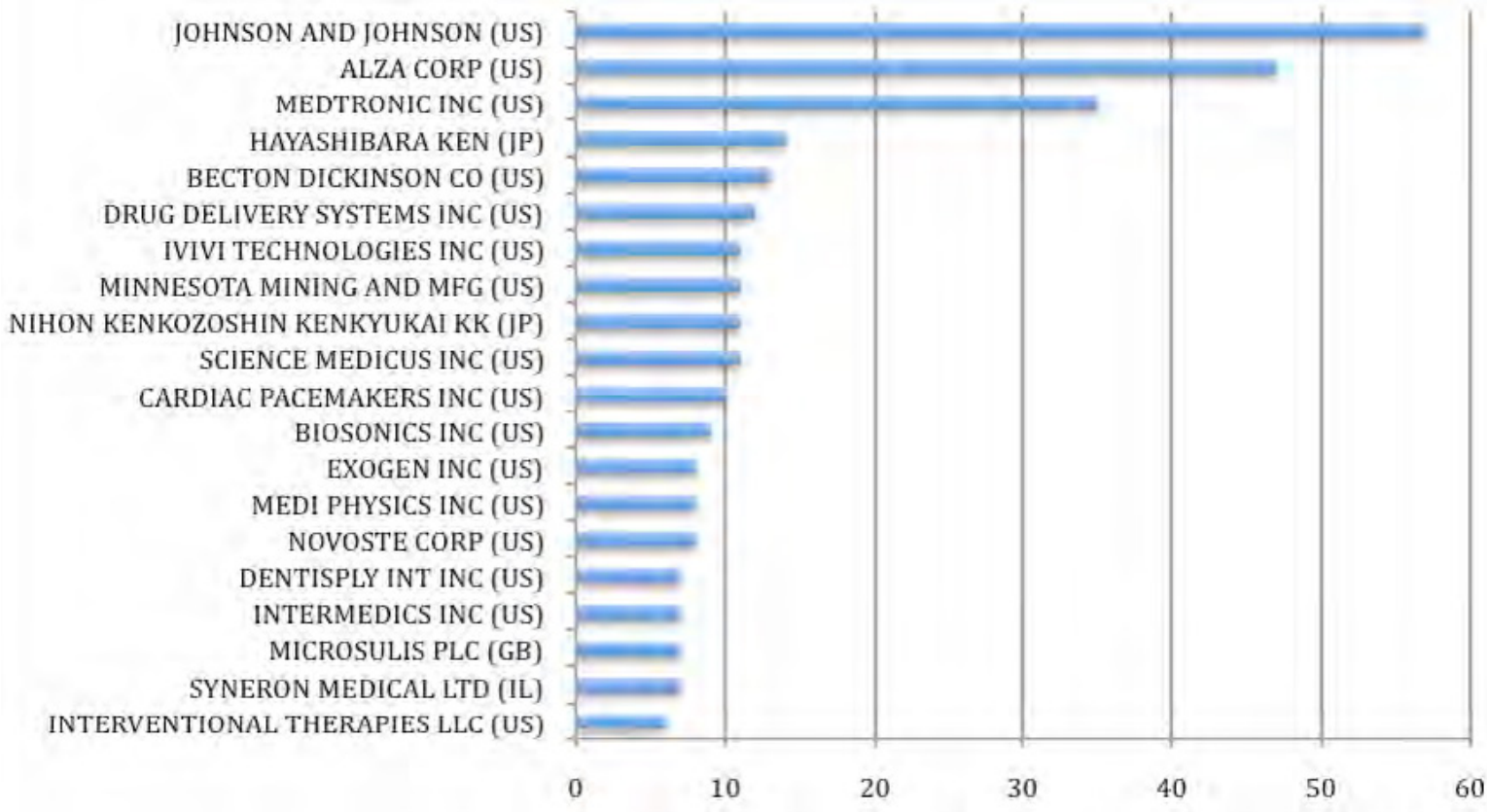

Graph 3. Companies with patent applications in the electro-medical equipment sector in Latin America between 1973 and 2010.

ISSN: 07 I8-2724. (http://www.jotmi.org)

Journal of Technology Management \& Innovation (c) Universidad Alberto Hurtado, Facultad de Economía y Negocios. 


\section{NB Countries in Latin America; countries of companies filing applications in Latin America.}

The distribution of companies in the electro-medical equipment sector with applications in Latin American countries, by country of filing, presented a variety of exploitation of protection rights. North American companies filed patent applications in 9 of the 10 Latin America countries (the exception being Cuba). Amongst these Latin American companies, the largest number of patent applications filed by North American companies occurs in Brazil and Mexico, both with $17 \%$. In addition, Brazil and Mexico were also the two biggest countries that were the subject of exploitation by other companies assigned to Europe and Asia. Relationships between companies and universities were identified in only 6 patents, including North American companies and universities.

- characteristics of the electro-medical equipment sector: the total production of I,687 patent applications in the electro-medical equipment sector in Latin America is distributed across all the subcategories that make up the International Patent Classification A6IN (Electrotherapy; Magnetotherapy; Radiation Therapy, Ultrasound Therapy), namely: A6IN I (Electrotherapy; Circuits therefor); A6IN 2 (Magnetotherapy); A6IN 5 (Radiation Therapy) and A6IN 7 (Ultrasound Therapy). Subcategories A6IN I and A6IN 5 were the most frequent classifications found amongst the 4 subcategories, representing $60 \%$ and $24 \%$ of the total number of applications, respectively (Table 2 ).
Distributed by country of filing, all the A6IN subcategories in the IPC were identified in Latin American countries with patent applications in the electro-medical equipment sector. There is a predominance of technologies classified in subcategory A6IN I (Electrotherapy; Circuits therefor) and A6IN 5 (Radiation Therapy) that were filed in almost all the countries of Latin-America, and in particular Brazil, Mexico and Argentina, representing $99 \%$ and $97 \%$ in these countries, respectively. In this context, it is noteworthy to see that the electro-medical equipment sector in Latin America is specifically concentrated in three countries, namely Brazil, Mexico and Argentina and the technologies filed encompass electrotherapy and radiation therapy.

\section{Conclusion}

It may be concluded that the electro-medical equipment sector in Latin America is in a state of growth, specifically in the last decade, with exponential growth in the number of patent applications in the sector, although the region still does not have a significant role to play in the patent application policies of international, and particularly, European countries. The production of patents registered in Latin America in this segment is still negligible when compared to the global total, representing a little over 1\% of worldwide production. There is a predominance of technologies that include electrotherapy and radiation therapy, primarily developed by North American companies (38\%), then Latin American companies, particularly Brazilian (25\%), European and Asian. These companies concentrate mar-

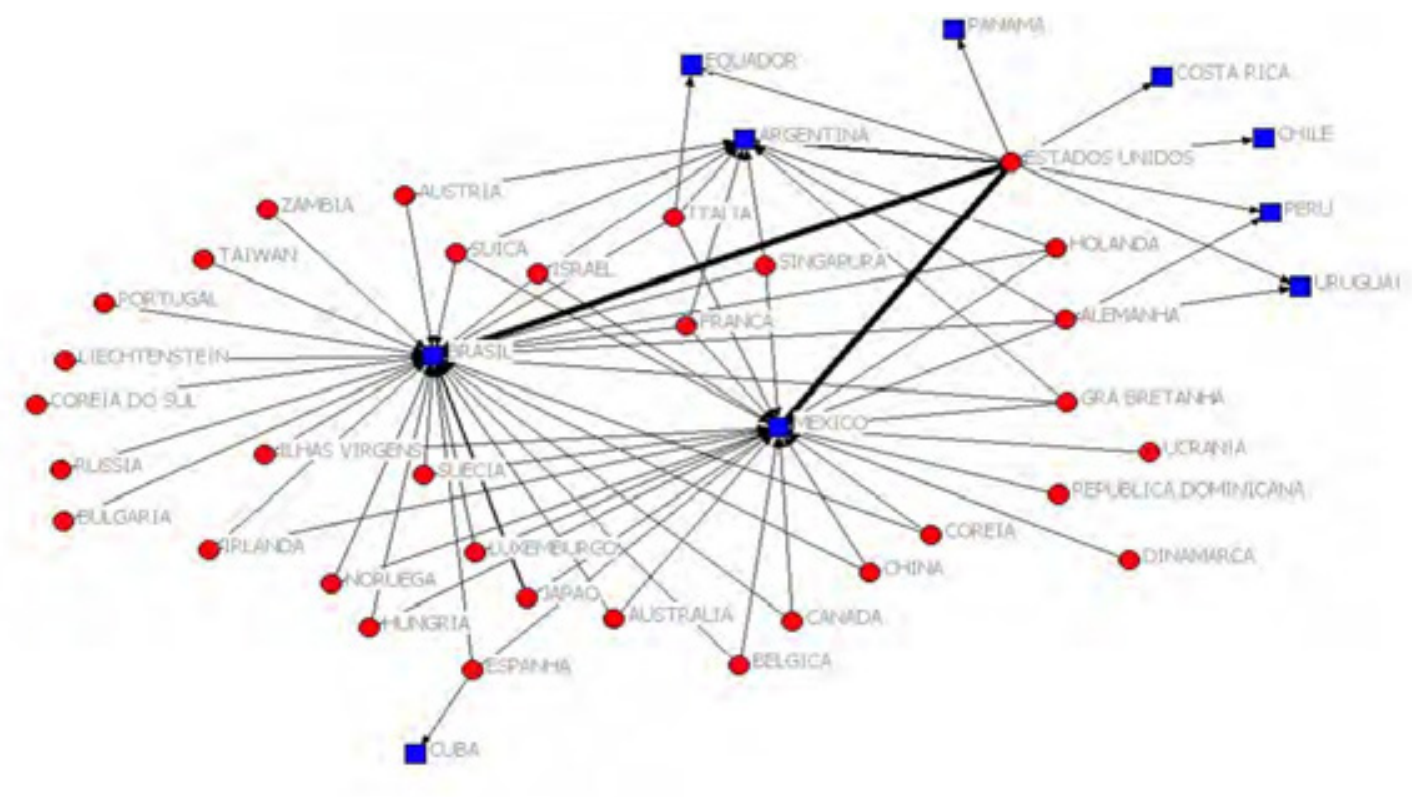

Graph 4. Countries with companies filing patent applications in the electro-medical equipment sector in Latin America between 1973 and 2010.

ISSN: 07 I8-2724. (http://www.jotmi.org)

Journal of Technology Management \& Innovation (c) Universidad Alberto Hurtado, Facultad de Economía y Negocios. 
ket exploitation rights in only a few Latin American companies, particularly Brazil, Mexico and Argentina, which together account for $99 \%$ of the total number of patent applications in the sector.

In the case of the North American companies, production is concentrated in 16 companies which represent $18 \%$ of producing companies in the area. It is possible, therefore, to deduce that Latin America was not seen as being an attractive market for $82 \%$ of technology producing companies in this sector, worldwide. As for patent production in universities filing applications in countries in Latin America, 26 patents ( $58 \%$ of the total) relate to patents of 17 North American universities and II (25\%) relate to the patents of Brazilian universities. A more detailed analysis of the distribution of these patents shows a higher concentration in production linked to Brazilian universities, in comparison with American universities where the number is more evenly distributed between the various universities, with the following high- lighted: California (4 patents) and Pennsylvania (3), while in Brazil the Federal University of Minas Gerais (UFMG) registered 5 patents and the University of São Paulo (USP) 3.

The results of the study allow us to meet the proposed objectives, providing evidence of the relative position of the sector and the countries of Latin America in relation to the potential world competition. However, further analysis should be undertaken for a better contextualization of the strategy adopted by companies when selecting the markets in which the applications will be filed and the participation of universities, especially Brazilian universities, in the system of innovation in the sector. Future studies might provide a better understanding of relationships between the stakeholders in the process of innovation in this sector, thus being able to contribute to providing support for science and technology policies for the sector and the improvement in innovation management by companies, as well as policies to encourage cooperation between universities and business.

\begin{tabular}{|c|c|c|c|c|c|c|}
\hline CIP Country & A6IN & A6IN I & A6IN 2 & A6IN 5 & A6IN 7 & Total \\
\hline Argentina & 4 & 162 & 11 & 26 & 0 & 203 \\
\hline Brazil & 23 & 887 & 173 & 386 & 54 & 1523 \\
\hline Chile & 0 & 1 & 0 & 0 & 0 & 1 \\
\hline Costa Rica & 1 & I & 0 & 0 & 0 & 2 \\
\hline Cuba & 0 & 4 & 1 & I & 0 & 6 \\
\hline Ecuador & 0 & 2 & 0 & 5 & 0 & 7 \\
\hline Mexico & 35 & 529 & 71 & 205 & 41 & 881 \\
\hline Panamá & 0 & 0 & 0 & I & 0 & I \\
\hline Peru & 0 & 3 & 0 & 3 & 0 & 6 \\
\hline Uruguay & 0 & 2 & 0 & 3 & 0 & 5 \\
\hline Total & 63 & $159 \mid$ & 256 & 630 & 95 & 2635 \\
\hline
\end{tabular}

Table 2. Distribution of electro-medical equipment sector patents filed in Latin America between 1973 and 2010 , by subcategory and country of filing.

Note: NB A6IN (Electrotherapy; Magnetotherapy; Radiation Therapy; Ultrasound Therapy), namely:A6IN I (Electrotherapy; Circuits therefor); A6IN 2 (Magnetotherapy);A6IN 5 (Radiation Therapy) and A6IN 7 (Ultrasound Therapy).

ISSN: 07 I8-2724. (http://www.jotmi.org)

Journal of Technology Management \& Innovation (C) Universidad Alberto Hurtado, Facultad de Economía y Negocios. 


\section{References}

CALLON, M.; Courtial, J.P.; Penan, H. (1995). Cienciometria: el estudio cuantitativo de la actividad científica. TREA, Oviedo.

FUJINO, A (2006). Avaliação dos impactos da produção científica na produção tecnológica. In: Poblácion, D.A.; Witter, G.P.; Silva, J.F.M. da (Orgs.). Comunicação e produção científica: contexto, indicadores, avaliação. Angellara, São Paulo. pp. 37I-386.

GIL,A.C. (2002). Como elaborar projetos de pesquisa.Atlas, São Paulo.

GUZMAN SANCHEZ, M.V. (1999). Patentometria: herramienta para el análisis de oportunidades tecnológicas. Universidad de La Habana, Cuba.

HYODO, T. (2010). Interação universidade-empresa: a produtividade científica dos inventores da Universidade de São Paulo. Universidade de São Paulo, 2010.

MARICATO, J. M. (2010). Dinâmica das relações entre Ciência e Tecnologia: estudo Bibliométrico e Cientométrico de múltiplos indicadores de artigos e patentes em biodiesel. Universidade de São Paulo, São Paulo.

MEYER, M. (2000). What is special about patent citations? Differences between scientific and patent citations. Scientometrics, 49(I), 93-123.

MOREIRA, M.L.;Velho, L. (2008). Pós-graduação no Brasil: da concepção ofertista linear para novos modos de produção do conhecimento - implicações para avaliação. Avaliação, 13(3), 625-645.

NARIN, F; Olivastro, D. Status report: linkage between technology and science. Research Policy, 2I, 237-249.

NARIN, F. (1995). Patents as indicators for the evaluation of industrial research output. Scientometrics, 34(3), 489-496.

NARIN, F. (1994). Patents bibliometrics. Scientometrics, 30, I47-I55.

PEREIRA C.A.; Bazi, R.E.R. Flow and social relationships of knowledge in Scince, Technology and Innovation: a patentometric study of Unicamp's technological production. Scientometrics, 8I, 6I-72.

SCHMOCH, U. (1997). Indicators and the relations between science and technology. Scientometrics, 38(I), I03-II6.
SPINAK, E. (2003). Indicadores cienciométricos de patentes: aplicaciones y limitaciones. Ricyt, Madrid. 


\section{APPENDIX I}

Worldwide distribution of patent records in the electro-medical equipment sector between $196 \mathrm{I}$ and 2010.

\begin{tabular}{|c|c|c|c|}
\hline RANKING & COUNTRY & PATENT RECORD & $\%$ \\
\hline 1 & United States of America & 36831 & 21,69 \\
\hline 2 & Japan & 27432 & 16,15 \\
\hline 3 & China & 15600 & 9,189 \\
\hline 4 & World Intellectual Property Organization (WIPO) & 14923 & 8,790 \\
\hline 5 & European Patent Office & 13295 & 7,831 \\
\hline 6 & Germany & $|209|$ & 7,122 \\
\hline 7 & Australia & 8641 & 5,090 \\
\hline 8 & Canada & 6117 & 3,603 \\
\hline 9 & Russian Federation & 5672 & 3,341 \\
\hline 10 & France & 3810 & 2,244 \\
\hline II & Korea (South) & 3210 & $\mathrm{I}, 890$ \\
\hline 12 & Áustria & 3140 & 1,849 \\
\hline 13 & United Kingdom & 2513 & 1,480 \\
\hline 14 & Soviet Union (USSR) & 2428 & 1,430 \\
\hline 15 & Spain & 1909 & 1,124 \\
\hline 16 & Brazil & 1018 & 0,599 \\
\hline 17 & Netherlands & 879 & 0,517 \\
\hline 18 & Italy & 817 & 0,481 \\
\hline 19 & Denmark & 781 & 0,460 \\
\hline 20 & Switzerland & 731 & 0,430 \\
\hline 21 & Sweden & 725 & 0,427 \\
\hline 22 & Belgium & 586 & 0,345 \\
\hline 23 & Ukraine & 547 & 0,322 \\
\hline 24 & Taiwan & 543 & 0,319 \\
\hline 25 & México & 514 & 0,302 \\
\hline 26 & South Africa & 487 & 0,286 \\
\hline 27 & Norway & 379 & 0,223 \\
\hline 28 & Israel & 361 & 0,212 \\
\hline 29 & Poland & 335 & 0,197 \\
\hline 30 & New Zealand & 284 & 0,167 \\
\hline 31 & Hong Kong & 271 & 0,159 \\
\hline 32 & Finland & 270 & 0,159 \\
\hline 33 & Portugal & 265 & 0,156 \\
\hline 34 & German Democratic Republic & 216 & 0,127 \\
\hline 35 & Hungary & 215 & 0,126 \\
\hline 36 & Czech Republic & 199 & 0,117 \\
\hline 37 & Greece & 163 & 0,096 \\
\hline 38 & Czechoslovakia & 160 & 0,094 \\
\hline 39 & Ireland & 157 & 0,092 \\
\hline 40 & Argentina & 133 & 0,078 \\
\hline 41 & Bulgária & 107 & 0,063 \\
\hline
\end{tabular}




\begin{tabular}{|c|c|c|c|}
\hline 41 & Eurasian Patent Organization & 107 & 0,063 \\
\hline 42 & Romania & 100 & 0,058 \\
\hline 43 & Republic of Moldova & 78 & 0,045 \\
\hline 44 & Yugoslavia/Serbia and Montenegro & 76 & 0,044 \\
\hline 45 & Singapore & 70 & 0,041 \\
\hline 46 & Luxembourg & 69 & 0,040 \\
\hline 47 & Turkey & 61 & 0,035 \\
\hline 48 & India & 55 & 0,032 \\
\hline 49 & Slovenia & 49 & 0,028 \\
\hline 50 & Slovakia & 48 & 0,028 \\
\hline 51 & Croatia & 39 & 0,022 \\
\hline 51 & Serbia & 39 & 0,022 \\
\hline 52 & Philippines & 30 & 0,017 \\
\hline 53 & Estonia & 22 & 0,012 \\
\hline 53 & Lithuania & 22 & 0,012 \\
\hline 54 & Iceland & 19 & 0,011 \\
\hline 55 & Egypt & 17 & 0,010 \\
\hline 56 & Monaco & 14 & 0,008 \\
\hline 57 & Indonesia & 13 & 0,007 \\
\hline 58 & African Intelectual Property Organization & 12 & 0,007 \\
\hline 59 & Latvia & 11 & 0,006 \\
\hline 60 & Morocco & 10 & 0,005 \\
\hline 61 & Ecuador & 6 & 0,003 \\
\hline 62 & Cuba & 5 & 0,002 \\
\hline 62 & Malaysia & 5 & 0,002 \\
\hline 62 & Peru & 5 & 0,002 \\
\hline 62 & Tajikistan & 5 & 0,002 \\
\hline 63 & Uruguay & 3 & 0,001 \\
\hline 64 & Malawi & 2 & 0,001 \\
\hline 64 & Zimbabwe & 2 & 0,001 \\
\hline 65 & African Regional Industrial Property Organization & 1 & 0,000 \\
\hline 65 & Bosnia and Herzegovina & 1 & 0,000 \\
\hline 65 & Chile & I & 0,000 \\
\hline 65 & Costa Rica & $\mathrm{I}$ & 0,000 \\
\hline 65 & Cyprus & $\mathrm{I}$ & 0,000 \\
\hline 65 & Panama & 1 & 0,000 \\
\hline 65 & Zambia & 1 & 0,000 \\
\hline TOTAL & 169756 & 100 & \\
\hline
\end{tabular}

